\title{
Comparative Study Gallbladder Contractility Index Using Ultrasound in Patients with and without Liver Cirrhosis
}

\author{
Hari Soekersi, ${ }^{1}$ Leni Santiana, ${ }^{1}$ Fetty Fatmawaty ${ }^{2,3}$ \\ ${ }^{1}$ Department of Radiology, Faculty of Medicine, Universitas Padjadjaran/Dr. Hasan Sadikin General Hospital, \\ Bandung, Indonesia, ${ }^{2}$ Radiology Study Program, Faculty of Medicine, Universitas Padjadjaran/Dr. Hasan Sadikin \\ General Hospital, Bandung, Indonesia, ${ }^{3}$ R. Syamsudin, S.H. Regional General Hospital, Sukabumi, Indonesia
}

\begin{abstract}
Liver cirrhosis leads to impairment of gallbladder contractility resulting in bile stasis and facilitate the development of gallstones that will aggravate the clinical symptoms of the patients. The gallbladder contractility index is an indicator of gallbladder motility measured using ultrasound as the radiological choice of modality. This study aims to determine differences in the gallbladder contractility index using ultrasound in patients with and without liver cirrhosis. This study was an observational study of comparative analytic with cross-sectional design with sampling conducted by consecutive admissions sampling at Dr. Hasan Sadikin General Hospital Bandung from December 2017 to February 2018. Statistical analysis than performed by using an independent $t$ test to find out the difference of gallbladder contractility index in patients with and without liver cirrhosis. A total of 22 subjects, 12 men, 10 women, with the youngest 37 years old and the oldest 70 years old. The result of the study was obtained mean fasting gallbladder volume $(35.56 \pm 22.16 \mathrm{~mL})$ and postprandial $(21.25 \pm 16.08 \mathrm{~mL})$ in patients with liver cirrhosis higher than without liver cirrhosis with mean fasting gallbladder volume $(16.50 \pm 4.14 \mathrm{~mL})$ and postprandial $(5.44 \pm 2.10$ $\mathrm{mL})$. The average gallbladder contractility index on patients with liver cirrhosis $(41.64 \pm 24.52 \%)$ smaller than without liver cirrhosis (66.73 $\pm 9.19 \%)$. The result of the statistical test showed that there was a significant difference in the gallbladder contractility index on patients with liver cirrhosis than without liver cirrhosis ( $\mathrm{p}=0.007, \mathrm{p} \leq 0.05)$. In conclusion, there was a significant difference in the gallbladder contractility index that measured by using ultrasound between the patients with and without liver cirrhosis.
\end{abstract}

Key words: Contractility index, gallbladder, liver cirrhosis, ultrasound

\section{Perbedaan Indeks Kontraktilitas Kandung Empedu Menggunakan Ultrasonografi pada Penderita Sirosis Hati dan tanpa Sirosis Hati}

\begin{abstract}
Abstrak
Sirosis hati menyebabkan gangguan indeks kontraktilitas kandung empedu yang mengakibatkan stasis cairan empedu dan memudahkan kejadian batu empedu yang akan memperberat gejala klinis pasien. Indeks kontraktilitas kandung empedu merupakan indikator motilitas kandung empedu yang diukur menggunakan ultrasonografi (USG) sebagai modalitas pilihan radiologi. Penelitian ini bertujuan mengetahui perbedaan indeks kontraktilitas kandung empedu menggunakan ultrasonografi pada pasien sirosis hati dan tanpa sirosis. Penelitian ini menggunakan studi observasional analitik komparatif dengan rancangan cross-sectional dan pengambilan sampel dilakukan secara consecutive admissions sampling di RSUP Dr. Hasan Sadikin Bandung dari bulan Desember 2017 hingga Februari 2018. Uji statistik menggunakan independent $t$ test. Subjek penelitian berjumlah 22, laki-laki 12 dan perempuan 10, serta usia termuda 37 tahun dan tertua 70 tahun. Hasil penelitian didapatkan volume rerata kandung empedu puasa $(35,56 \pm 22,16 \mathrm{~mL})$ dan pascaprandial $(21,25 \pm 16,08 \mathrm{~mL})$ pada pasien sirosis hati lebih besar daripada tanpa sirosis hati dengan volume rerata kandung empedu puasa $(16,50 \pm 4,14 \mathrm{~mL})$ dan pascaprandial $(5,44 \pm 2,10 \mathrm{~mL})$. Indeks kontraktilitas rerata kandung empedu penderita sirosis hati $(41,64 \pm 24,52 \%)$ lebih rendah dibanding dengan tanpa sirosis hati $(66,73 \pm 9,19 \%)$. Hasil uji statistik menunjukkan terdapat perbedaan bermakna antara indeks kontraktilitas kandung empedu penderita sirosis hati dan tanpa sirosis hati $(\mathrm{p}=0,007 ; \mathrm{p} \leq 0,05)$. Simpulan, terdapat perbedaan bermakna antara indeks kontraktilitas kandung empedu menggunakan USG pada penderita sirosis hati dan tanpa sirosis hati.
\end{abstract}

Kata kunci: Indeks kontraktilitas, kandung empedu, sirosis hati, ultrasonografi

Received: 7 May 2018; Revised: 26 January 2020; Accepted: 2 March 2020; Published: 30 April 2020

Correspondence: Fetty Fatmawaty, dr., Sp.Rad. R. Syamsudin, S.H. Regional General Hospital. Jln. Rumah Sakit No. 1, Sukabumi 43113, West Java, Indonesia. E-mail: tototi.ff@gmail.com 


\section{Introduction}

Liver cirrhosis is the third leading cause of death in patients who are 45-46 years old (after cardiovascular and cancer). Liver cirrhosis is a disease characterized by diffuse and chronic inflammation of the liver progressively with distorted images of the hepatic architecture and the formation of regenerative nodules. ${ }^{1,2}$ Worldwide, liver cirrhosis ranks seventh as the cause of death. There are more male patients with liver cirrhosis compared with women with a ratio of about 1.6:1. The average age group is 30-59 years old, with a peak of around the age of 40-49 years old. ${ }^{3,4}$ In 2015, the World Health Organization (WHO) reported that 720,000 deaths caused by liver cirrhosis in the world. ${ }^{5}$

In 2012, liver cirrhosis in Indonesia is the sixth cause of death, with 48.9 thousand deaths. The incidence of liver cirrhosis in Indonesia due to hepatitis B ranged between 21.2-46.9\% and hepatitis C ranged 38.7-73.9\%. ${ }^{6,7}$ In Dr. Hasan Sadikin General Hospital Bandung hospitalized patients with liver cirrhosis in 2012 until September 2017 were about 365 people, and about 1,716 people went through internal medicine polyclinic. ${ }^{8}$

Patients with liver cirrhosis have a higher incidence and prevalence of gallstones than the general population, with a prevalence of $25-30 \%$. Liver cirrhosis is one of the significant risk factors for the formation of gallstones. ${ }^{9}$ Gallstones in patients with liver cirrhosis are asymptomatic and symptomatic to cause complications. In patients with liver cirrhosis, Child-Pugh A and B with symptomatic gallstones recommended doing cholecystectomy before the complication that will aggravate the patient clinical condition and before the severe condition of the liver symptoms. ${ }^{10}$ The formation of gallstones in patients with liver cirrhosis is due to several factors; one of them is due to bile stasis caused by the decrease in gallbladder contractility index. ${ }^{11}$

The decrease in the gallbladder contractility index is due to the humoral, hypoalbuminemia, and also neurological disorders. Neurological disorders in patients with liver cirrhosis are in the form of neuropathy. The severity of this neuropathy is proportional to an increase in liver damage. The patients with liver cirrhosis, especially decompensated liver cirrhosis, usually have autonomic dysfunction directly affect the contractility of the gallbladder through the neural path..$^{12}$ Gallbladder contractility disorder in cirrhotic patients is also affected by the thickening of the gallbladder wall. This thickening is due to edema and structural changes in the gallbladder wall due to hypoalbuminemia and portal hypertension. In addition to the above, the disorder of gallbladder contractility in patients with liver cirrhosis also influenced by humoral changes. ${ }^{13-17}$

Humoral changes that occur in liver cirrhosis are due to cholecystokinin (CCK) receptor resistance in the gallbladder. Thus, the contraction of the gallbladder disrupted. Besides, decreased hepatic clearance also occurs in patients with liver cirrhosis, increasing the level of intestinal peptides that affect the relaxation of the gallbladder wall. Gallbladder contractility disorders in patients with liver cirrhosis assessed by evaluating the gallbladder contractility index using ultrasound. ${ }^{13}$

Ultrasound is the preferred modality for assessing the gallbladder contractility index by measuring the volume of the gallbladder, and postprandial. Ultrasound is a radiological modality that is accurate, noninvasive, cheap, easy to obtain, no radiation and repeated to assess the gallbladder contractility index..$^{12,14,18}$

A research conducted by Buzaş et al. ${ }^{19}$ suggested that the volume of gallbladder fasting and postprandial volume using ultrasound was higher in patients with liver cirrhosis. Loreno et al. ${ }^{14}$ also suggest that there was a difference in the gallbladder contractility index in patients with liver cirrhosis compared with no liver cirrhosis. Acalovschi ${ }^{13}$ suggests that there was a decreasing index of gallbladder contractility in patients with liver cirrhosis following the severity of cirrhosis. It is contrary to research conducted by Kul et al., ${ }^{12}$ suggesting that therewas anincreaseingallbladder contractility index in patients with liver cirrhosis compared with healthy control. Shirole et al. ${ }^{11}$ suggest that patients with liver cirrhosis have a higher prevalence of the occurrence of gallstones than in a healthy population. One of the causes is a decrease in the gallbladder contractility index. Because of differences in the above studies, the researchers will determine differences in the gallbladder contractility index using ultrasound in patients with and without liver cirrhosis.

\section{Methods}

This study was an analytic observational study 
with a cross-sectional design conducted from December 2017 to February 2018. Sampling was patients with liver cirrhosis and without liver cirrhosis in Dr. Hasan Sadikin General Hospital Bandung, who matched the inclusion criteria with consecutive admissions method (based on the order of the registered patient). The inclusion criteria were patients with adult liver cirrhosis diagnosed from the Gastroentero-hepatology clinic of Dr. Hasan Sadikin General Hospital Bandung and undiagnosed liver cirrhosis that had gone through ultrasound examination in the Department of Radiology Dr. General Hospital Hasan Sadikin and willing to follow the research. Exclusion criteria for this study were patients with a history of bile disease, gallbladder hydrops, diabetes mellitus, post gastric resection surgery, and patients who were pregnant.

Statistical analysis used to describe the difference of gallbladder contractility index using ultrasound in patients with and without liver cirrhosis. A statistical test using the parametric method, independent $t$ test performed using SPSS version 22.0 for Windows at a $95 \%$ confidence level.
Ethical approval for this study has obtained from the Health Research Ethics Committee of Dr. Hasan Sadikin General Hospital Bandung with the letter number: LB.04.01/A05/EC/379/ XII/2017.

\section{Results}

Table 1 shows that by gender, there were more male patients than females with and without liver cirrhosis who came to Dr. Hasan Sadikin General Hospital as many as 12 of 22.

The differences in gallbladder contractility index using ultrasound in patients with and without liver cirrhosis in Dr. Hasan Sadikin General Hospital can be seen in Table 2.

Based on Table 2, it can be seen that the average volume of fasting gallbladder using ultrasound on the liver cirrhosis patients is $35.56 \mathrm{~mL}$, with a standard deviation of 22.16 $\mathrm{mL}$. Patients without liver cirrhosis was 16.50 $\mathrm{mL}$, with a standard deviation of $4.14 \mathrm{~mL}$. The mean postprandial gallbladder volume using ultrasound in patients with liver cirrhosis was $21.25 \mathrm{~mL}$, with a standard deviation of $16.08 \mathrm{~mL}$,

Table 1 Characteristics of Study Subjects by Age and Gender in Patients with and without Liver Cirrhosis

\begin{tabular}{cccc}
\hline Age and Gender & $\mathbf{n = 2 2}$ & Average (SD) & Median (Min-Max) \\
\hline Age (years) & 5 & & \\
$30-40$ & 8 & $49.45(9.53)$ & $48(37-70)$ \\
$41-50$ & 9 & & \\
$>50$ & & & \\
Gender & 12 & & \\
Male & 10 & & \\
Female & &
\end{tabular}

Table 2 The Differences in Gallbladder Contractility Index Using Ultrasound in Patients with and without Liver Cirrhosis

\begin{tabular}{|c|c|c|c|c|c|}
\hline \multirow{3}{*}{ Gallbladder } & \multicolumn{4}{|c|}{ Liver Cirrhosis Incident } & \multirow{3}{*}{$\underset{\text { Value }^{*}}{\mathbf{p}}$} \\
\hline & \multicolumn{2}{|c|}{ Liver Cirrhosis } & \multicolumn{2}{|c|}{$\begin{array}{l}\text { Without Liver } \\
\text { Cirrhosis }\end{array}$} & \\
\hline & Average & SD & Average & SD & \\
\hline Fasting gallbladder volume & 35.56 & 22.16 & 16.50 & 4.14 & \\
\hline Postpartum gallbladder volume & 21.25 & 16.08 & 5.44 & 2.10 & 0.007 \\
\hline Gallbladder contractility index & 41.64 & 24.52 & 66.73 & 9.19 & \\
\hline
\end{tabular}

Note: "Independent t test 


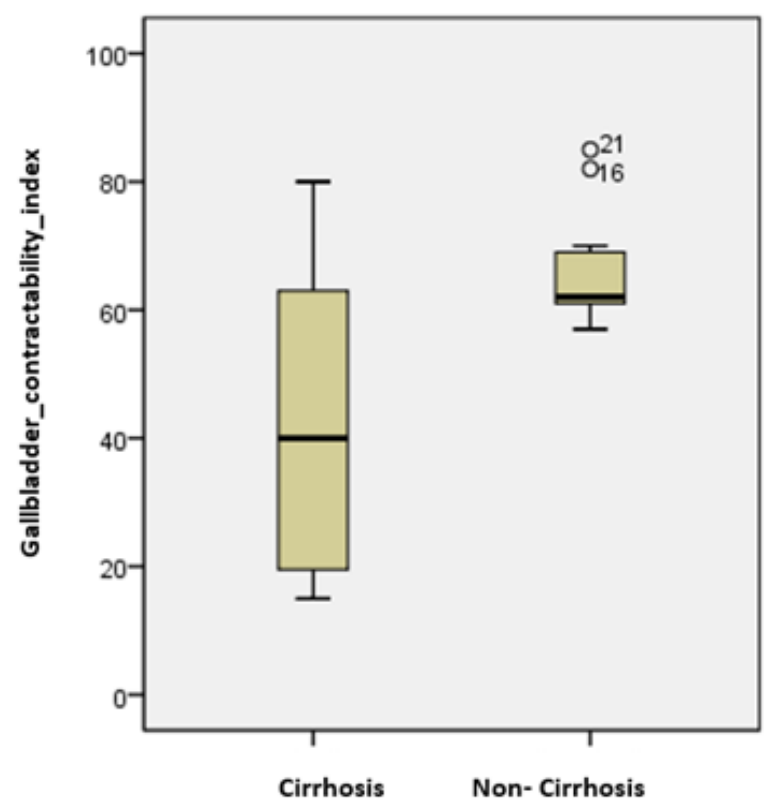

\section{Figure The Differences in Gallbladder Contractility Index Using Ultrasound in Patients with and without Liver}

whereas in patients without liver cirrhosis was $5.44 \mathrm{~mL}$, with a standard deviation of $2.10 \mathrm{~mL}$.

Based on Table 2, it can be seen that the average gallbladder contractility index using ultrasound in patients with liver cirrhosis was $41.64 \%$, with a standard deviation of $24.52 \%$. Patients without liver cirrhosis were $66.73 \%$, with a standard deviation of $9.19 \%$. The independent $t$ test result on a 95\% confidence degree shows that there was a significant difference in gallbladder contractility index using ultrasound in patients with and without liver cirrhosis $(\mathrm{p}=0.007$, $\mathrm{p} \leq 0.05$ ).

The differences in gallbladder contractility index using ultrasound in patients with and without liver cirrhosis is in Figure.

\section{Discussion}

The results of age-based, the age distribution of most patients with liver cirrhosis in this study were in the age group $>50$ years. It is by the research conducted by Hussain et al., ${ }^{10}$ which states that patients with liver cirrhosis are more common in middle age and older age due to disease progression of liver cirrhosis that usually takes $5-10$ years. Patients with liver cirrhosis in this study were mostly male. The results are consistent with Basic Health Research 2013 that patients affected by hepatitis are more likely to be men even when it is less significant and mostly work-related that often occurs in patients who work as farmers/laborers or fishermen. ${ }^{20,21}$

The results based on fasting gallbladder volume show that the average fasting gallbladder volume in liver cirrhosis patients was $35.56 \mathrm{~mL}$, with a standard deviation of $22.16 \mathrm{~mL}$. The results are higher than those without liver cirrhosis with an average fasting gallbladder volume of $16.5 \mathrm{~mL}$ and a standard deviation of $4.14 \mathrm{~mL}$. It suggests that most of the volume of the fasting gallbladder in patients with liver cirrhosis is more significant than without liver cirrhosis. It is under research conducted by Buzaş et al. ${ }^{19}$ and Loreno et al. ${ }^{14}$ state that the average gallbladder volume of fasting patients with liver cirrhosis is higher than without liver cirrhosis. The mechanism of fasting gallbladder volume of patients with liver cirrhosis larger than without liver cirrhosis is suspected because increased intestinal peptides lead to the relaxation of gallbladder muscles and autonomic nervous disorders resulting in lower gallbladder contraction in the patients with liver cirrhosis.

The average postprandial gallbladder volume in liver cirrhosis patients is $21.25 \mathrm{~mL}$ with a standard deviation of $16.08 \mathrm{~mL}$, while in the group without liver cirrhosis, the mean postprandial gallbladder volume is $5.44 \mathrm{~mL}$ and a standard deviation of $2.1 \mathrm{~mL}$. It appears that the average of postprandial gallbladder volume in most liver cirrhosis patients tends to be higher than the average of postprandial gallbladder volume in patients without liver cirrhosis. ${ }^{22}$

Based on the average gallbladder contractility index, the index of biliary tactility in liver cirrhosis patients was $41.64 \%$, with a standard deviation of $24.52 \%$. In comparison, the average of gall gallbladder contractility in the group without liver cirrhosis was $66.73 \%$, with a standard deviation of $9.19 \%$. It is under research conducted by Loreno et al. ${ }^{14}$ and Acalovschi, ${ }^{13}$ who suggest that the gallbladder contractility index in patients with liver cirrhosis is lower than without liver cirrhosis.

Independent $t$ test analysis at 95\% confidence degree showed that there is a statistically significant difference between gallbladder contractility index using ultrasound in patients with and without liver cirrhosis $(\mathrm{p}=0.007$, $\mathrm{p} \leq 0.05)$. It is consistent with the research 
conducted by Loreno et al. ${ }^{14}$ and Acalovschi, ${ }^{13}$ who suggest that there is a significant difference in the gallbladder contractility index of patients with and without liver cirrhosis.

The causes of gallbladder contractility index differences in patients with liver cirrhosis may due to a decrease in CCK receptor sensitivity in the gallbladder, autonomic neuropathy, hypoalbuminemia, and increased concentrations of intestinal peptides that affect gallbladder muscle relaxation. ${ }^{13}$

\section{Conclusion}

There was a significant difference in gallbladder contractility index using ultrasound in patients with and without liver cirrhosis in Dr. Hasan Sadikin General Hospital Bandung.

\section{Conflict of Interest}

There is no ethical/legal conflict involved in the article. All authors have no relevant financial interests related to the material.

\section{References}

1. Siregar GA, Tampubolon SE. Comparison of lipid profile between degrees of severity of hepatic cirrhosis in Haji Adam Malik General Hospital Medan. IOP Conf Ser Earth Environ Sci. 2018:125:012216.

2. Yeom SK, Lee $\mathrm{CH}$, Cha SH, Park CM. Prediction of liver cirrhosis, using diagnostic imaging tools. World J Hepatol. 2015;7(17):2069-79.

3. Zatoński WA, Sulkowska U, Mańczuk M, Rehm J, Boffetta P, Lowenfels AB, et al. Liver cirrhosis mortality in Europe, with special attention to central and eastern Europe. Eur Addict Res. 2010;16(4):193-201.

4. Blachier M, Leleu H, Peck-Radosavljevic M, Valla DC, Roudot-Thoraval F. The burden of liver disease in Europe: a review of available epidemiological data. J Hepatol. 2013;58(3):593-608.

5. World Health Organization (WHO). Global hepatitis report 2017. Geneva: WHO; 2017.

6. Widjaja FF, Karjadi T. Pencegahan perdarahan berulang pada pasien sirosis hati. J Indon Med Assoc. 2011;61(10):417-24.

7. Nurdjanah S. Sirosis hati. In: Sudoyo AW, Setiyohadi B, Alwi I, Simadibrata KM, Setiati
S, editors. Buku ajar ilmu penyakit dalam. $6^{\text {th }}$ Edition. Jakarta: Interna Publishing; 2014. p. 1978-83.

8. Sistem Informasi Rumah Sakit (SIRS) RSUP Dr. Hasan Sadikin (RSHS). Pasien sirosis hati 2012-2017. Bandung: SIRS RSHS; 2017.

9. Li X, Guo X, Ji H, Yu G, Gao P. Gallstones in patients with chronic liver diseases. Biomed Res Int. 2017;2017:9749802.

10. Hussain A, Nadeem MA, Nisar S, Tauseef $\mathrm{H}$. Frequency of gallstones in patients with liver cirrhosis. J Ayub Med Coll Abbottabad. 2014;26(3):341-3.

11. Shirole NU, Gupta SJ, Shah DK, Gaikwad NR, Sankalecha TH, Kothari HG. Cirrhosis of liver is a risk factor for gallstone disease. Int J Res Med Sci. 2017;5(5):2053-6.

12. Kul K, Serin E, Yakar T, Coşar AM, Özer B. Autonomic neuropathy and gallbladder motility in patients with liver cirrhosis. Turk J Gastroenterol. 2015;26(3):254-8.

13. Acalovschi M. Gallstones in patients with liver cirrhosis: incidence, etiology, clinical and therapeutical aspects. World J Gastroenterol. 2014;20(23):7277-85.

14. Loreno M, Travali S, Bucceri AM, Scalisi G, Virgilio C, Brogna A. Ultrasonographic Study of Gallbladder Wall Thickness and Emptying in Cirrhotic Patients without Gallstones. Gastroenterol Res Pract. 2009;2009:683040.

15. Butt Z, Hyder Q. Cholelithiasis in hepatic cirrhosis: evaluating the role of risk factors. J Pak Med Assoc. 2010;60(8):641-4.

16. Son JY, Kim YJ, Park HS, Yu NC, Ko SM, Jung SI, et al. Diffuse gallbladder wall thickening on computed tomography in patients with liver cirrhosis: correlation with clinical and laboratory variables. J Comput Assist Tomogr. 2011;35(5):535-8.

17. Mohammadi A, Ghasemi-Rad M, Mohammadifar M. Differentiation of benign from malignant induced ascites by measuring gallbladder wall thickness. Maedica (Buchar). 2011;6(4):282-6.

18. Popescu A, Sporea I. Ultrasound examination of normal gall bladder and biliary system. Med Ultrason. 2010;12(2):150-2.

19. Buzaș C, Chira O, Mocan T, Acalovschi M. Comparative study of gallbladder motility in patients with chronic HCV hepatitis and with HCV cirrhosis. Rom $J$ Intern Med. 2011;49(1):37-44.

20. Indonesia Agency of Health Research 
and Development, Ministry of Health of Republic of Indonesia. Basic health research (Riskesdas) 2013 [Internet]. Jakarta: Indonesia Agency of Health Research and Development, Ministry of Health of Republic of Indonesia; 2013 [cited 2017 June 15]. Available from: http://labdata.litbang. kemkes.go.id/ccount/click.php?id=10.

21. Pusat Data dan Informasi, Kementerian Kesehatan Republik Indonesia. Situasi dan analisis hepatitis [Internet]. 2014 September [cited 2018 February 20]. Available from: https://www.kemkes.go.id/resources / download/pusdatin/infodatin/infodatinhepatitis.pdf.

22. Abdelmaksoud MA, El-Shamy MH, Hussein HIM, Bihery AS, Ahmed H, El Hady HA. Frequency of cholelithiasis in patients with chronic liver disease: a hospital-based study. AJIED. 2016;6(3):134-41. 